\title{
Accommodation crisis: the racialization of travellers in twenty-first century England
}

\section{Steve Garner}

To cite this article: Steve Garner (2017): Accommodation crisis: the racialization of travellers in twenty-first century England, Ethnic and Racial Studies, DOI: 10.1080/01419870.2017.1380213

To link to this article: https://doi.org/10.1080/01419870.2017.1380213

\section{曲 Published online: 09 Oct 2017.}

Submit your article to this journal 주

Џlll Article views: 146

Q View related articles $\sqsubset$

View Crossmark data $₫$ 


\title{
Accommodation crisis: the racialization of travellers in twenty-first century England
}

\section{Steve Garner}

Department of Criminology and Sociology, Birmingham City University, Birmingham, UK

\begin{abstract}
Racialization is frequently deployed but seldom defined precisely. The agent(s) and mechanisms of the process are often not analysed. Such processes have multiple agents, mechanisms and rationales, all of which may change over time. The key agents of the racialization of Gypsy/Travellers in England have historically been the State and the media. This article claims that a key mechanism in the racialization of Gypsy-Travellers in the twenty-first century is the English planning system. There has been a long-term racialization of Gypsy-Travellers based around criminality, dirt and various threats to order. Gypsy-Travellers respond to the State's criminalization of their cultures by both adjusting their degree of mobility, and engaging with the discriminatory planning system to procure more advantageous outcomes. Gypsy-Travellers' "cultural adaptations" end up further embedding the existing racist frame, in which they unfairly gain advantage over sedentary people by simultaneously infringing rules and claiming they are discriminated against.
\end{abstract}

ARTICLE HISTORY Received 14 December 2016; Accepted 7 August 2017

KEYWORDS Gypsy-Travellers; racialization; planning; the state; racism; sedentary; mobility

\section{Introduction}

In popular understandings of racism in Britain there is a blind spot in relation to Gypsy-Travellers. It is also a grey area in respect to the use of the concept of racialization. They are white Europeans, runs the logic, therefore the antipathy felt by other white Europeans towards Gypsy-Travellers cannot be "racist". The relatively new language of ethnicity, and the incorporation of Gypsy-Travellers into the category "minority ethnic group" in both the UK and Northern Ireland (Clark 2006) enables "race" to be discursively sidestepped. ${ }^{1}$ Moreover, sedentary people's responses are often presented as "natural", generated by the behaviour of Gypsy-Travellers and therefore just descriptive, and "not really racist" (Goodman and Rowe 2013; Rowe and Goodman 2014). Scholarly analysis of Gypsy-Travellers' social relationships with sedentary society that centre "race" or racism (Bhopal 2011; Holloway 2003; Morris 2000) is also quite thin 
on the ground. Moreover, in contemporary populist discourse Gypsy-Travellers remain ongoing objects of contempt (Gentleman 2017).

On the contrary, I argue elsewhere (Garner 2007) first, that white European migrant and religious groups have been racialized through combinations of culture and economic positioning. Second, Gypsy-Travellers have historically been racialized in a number of different ways, and that the content and context of this process, in terms of the ideas and their forms of application, can change over time. In this article, I make and evidence two claims. First, that this racialization can assume an institutional form; and second, that the most significant framing context for racialization in the twenty-first century is the new relationship between Gypsy-Travellers and the planning regulations.

Racialization is frequently deployed but seldom defined precisely. It is often used as an outcome: a process and/or a group, for example, is thus posited as "racialized". The agent(s) and the mechanisms of the process are sometimes explored and analysed, but often not. I maintain that such processes have multiple agents, mechanisms and rationales, and that all of these may change over time. In terms of the racialization of Gypsy-Travellers in England, the key agents have historically been the State (Taylor 2008) and the media (Morris 2000). In this case study, I make the argument that the crucial mechanism through which racialization occurs is now the planning process. Due to recent legislative developments, which have criminalized nomadic cultures and closed off their space of operation, the planning process currently enables a longstanding racializing discourse to coalesce in new ways around particular Gypsy-Traveller practices that are themselves responses to changes in the legal and political context.

Before engaging with the key elements of the new configuration of forces impacting the racialization of Gypsy-Travellers, we will need to revisit the concept of racialization.

\section{Racialization}

Racialization is a master concept in social science's engagement with "race" and "ethnicity", appearing as keywords and in the titles of thousands of scholarly texts. However, given the extent of its deployment, its theoretical treatment and development is relatively meagre. Indeed, aside from the Murji and Solomos (2005) collection, explicit theoretical contributions to the study of racialization have been few and far between.

We can conceptualize racialization as above all a process (thus evoking a historical trajectory) in which ideas and practices of "race" are injected into a social relationship, as properties of people (Garner 2013; Maldonado 2009); places (Durrheim and Dixon 2001); spaces (Lipsitz 2007); institutions (Brewer and Heitzeg 2008; Carter, Harris, and Joshi 1987; Harell, Soroka, and 
Ladner 2014), relationships (Eng 2010), inter alia. In these examples, there are implicitly agents, mechanisms, subjects and objects, although these are seldom given explicit focus in the work on racialization. So the argument is that racialization is both widely deployed and under-theorized. Here I attempt to extend theory a little, in a speculative argument attempting to delineate the specifics of how an institution may shape the process of a particular group is racialized.

Racialization is built on the concept of "race": a political and social construction. "Race" has historically been about both bodies and culture, and their ideological entwining within a hierarchical and analytical frame used to reflect and generate power relationships: the biologization of culture and the culturalization of bodies are mutually reinforcing processes. "Race" is thus never only a matter of skin colour. Fox, Moroşanu, and Szilassy (2015) for example, demonstrate a variety of ways in which Eastern European migrants in contemporary Britain find themselves implicated in different positions of the racialized hierarchy.

We should at least query the notion that racialization is a one-way process dominated in every case and at all times by the more powerful of the actors. Scholarship on racialization has hitherto largely erred on this side of the equation. Wolfe $(2002,58)$ argues for instance that "racialisation is an exercise of power in its own right, as opposed to a commentary that enables or facilitates a prior exercise of power". This gives the impression that racialization is all about the impacts that the dominant have on the subaltern. Gypsy-Travellers were turned into racialized Others centuries ago, but they are still being racialized in different ways, as well as racializing themselves.

I am not alone in pointing out that groups self-racialize, or "reflexively" racialize (Parker and Song 2006) as an everyday practice, or as a collective response to oppression, be it perceived or actual. ${ }^{2}$ This reflexive racialization may assume various institutional forms; political movements and campaigns; self-help charities; websites; an array of self-affirming identity practices including participation in humour, music, worship, etc. Much of this appears to escape the scholarly categorization as "racialization" when it is de facto socialization into forms of "blackness", "whiteness", "British Chineseness", "Californian Korean-Americanness", etc. Few of these practices are gender-neutral or unaffected by the national context in which they take place, by the way, which is why I suggest that paradoxically, racialization is never exclusively about "race".

\section{The state}

The racialization of Gypsy-Travellers by the State goes back to the Renaissance period, when the distinction between nomadic and sedentary began to be read as pathological and civilizational (Quinn 1966). States across Europe 
identify them as dangerous from the fifteenth century: the first piece of explicitly anti-nomadic legislation, banning Travellers, was passed in Lucerne in 1471 (Mayall 2004). A set of similar laws were passed across Europe over the next century and a half, including a raft of increasingly draconian ones in Tudor England, where by 1554 the death penalty had been imposed as a punishment for Gypsies. Typically they were constructed as dirty and immoral criminals and sorcerers, not included in Christian communities (Kenrick and Puxon 1972). Such categorizing practices culminated, nearly four centuries later, in the rounding up, incarceration and mass murder of half a million European Gypsy-Travellers in concentration camps (The "Parajmos"). In post-war Europe the persecution of Gypsy-Travellers has proceeded mainly through a range of vigilante and/or police actions backed up by racialized discourse and representations (Bancroft 2001; Clough Marinaro and Sigona 2011; Nicolae and Slavik 2003).

Goldberg (2000) and Foucault (2003) have clarified the state's role in racialization, pointing out that its control of population and the "technologies" around such control are predicated on binaries and hierarchies: the nation/ the Other; men/women; the civilized/ the uncivilized; the productive/the unproductive, and how in the period of European and North American state formation, these binaries fitted precisely onto a map of the colonizing and colonized world. Yet one key binary (sedentary civilization/nomadic barbarity) is absent from both those authors' texts, but is clearly an important one in specific parts of the colonial enterprise such as Ireland (Quinn 1966), and very significant where indigenous peoples are semi-nomadic, in the Americas and Australasia. In those locations the indigenous are constructed by colonizing forces as neither having permanent rights to the land (because they are not settled in specific places), nor having earned their position through having dominated and transformed nature (into ordered and productive agricultural space).

So what work does this concept do, and for whom? First, it enables scholars to study "race" in formation rather than as an entity that has an a priori existence; and allows us to understand a sweep of historical change, the contextual specificity of particular instances of racialization, as well as the commonalities of ideas and practices. In other words, racialization is not only one-way traffic from the powerful, or about the behaviour of minorities, but a social relationship in which the less powerful also have some agency. For the actors, racialization is a Foucauldian technology of control, or the basis of marshalling resistance through producing identities and, potentially, political projects reversing the stigma generated by the racialization of the powerless by the powerful. Failure to theorize racialization leaves it implicitly as a nebulous, one-size-fits-all concept, thus missing the point about what it does, in practice, for different groups at different moments. 
There is a case to be made for using a different term to cover the reflexive and project-oriented racialization processes of the relatively less powerful. Indeed, for the remainder of this article I will use the term "reflexive racialization" to distinguish this aspect.

\section{The racializations of Gypsy-Travellers}

It should also be emphasized at the outset that "Gypsy-Traveller" is itself an exonymic descriptor that is most of the way to being a racialized term, connoting the effects of racialization on a set of geographically and culturally diverse groups (Stewart 2013). There are obviously cultural differences between Romani(chals), Irish Travellers, Roma and other groups in England, for example, while class and gender (Casey 2014) distinctions are present within groups. "Gypsy-Traveller" is being used as shorthand here.

However, the amalgamation of a variety of groups into the abstract "GypsyTravellers" is also occasionally used as a tactic by national and Europeanbased organizations, and coalitions between them, mindful of the cultural and historical distinctions between the groups that fall (or were they pushed?) into this category ${ }^{3}$ - in order to obtain funding, and acquire authority to intervene in formal and informal power-sharing and power-broking activities.

McGarry (2014) concludes that such inter-ethnic movements are unsuccessful. They have achieved ethnic minority status in the UK and Northern Ireland, which equates to a box in the Census, and automatic membership of particular committees. However, if success is measured in terms of health, quality of housing, educational attainment, for example (Cemlyn et al. 2009), or media and political representation, then this "recognition" has not yet generated corresponding "redistribution". While the available statistics are old, the last exercise aimed at measuring Traveller health in the UK (Parry et al. 2007) identified significant discrepancies between their health status and that of the settled population, in terms of access to healthcare; suffering from long-term illness, life expectancy, etc. Most importantly, the discrepancies exceed what could be expected if samples are controlled for class, indicating that other factors explain the extent of the inequalities (Van Cleemput 2012). Educational outcomes are dominated by highdropout rates and experiences of racism and exclusion (Bhopal 2011). Longterm processes of racialized exclusion are not new. Indeed the argument here is about the development of one key site (planning regulations) in the ongoing racialization process rather than a claim that this site overrides or subsumes others.

Sedentarist popular culture representations of, and discourse about GypsyTravellers in Britain have long associated them with dirt, theft, tribalism and a lack of economic productivity (Holloway 2003, 2005; Sibley 1981). Experiences 
of Gypsy-Travellers (Powell 2013) commonly involve negative experiences with police and often being checked for licence, tax, etc., indicating their association with cheating regulations and tax avoidance.

Moreover, even the construct of "mobile" and "sedentary" cultures should alert us to the role of the State in racializing populations, as Myers (2015) points out. In education discourses for example, the sedentary/non-sedentary binary is exclusively applied to discussions of Gypsy-Travellers, whereas:

... mobility itself can be better understood in terms of an axis between sedentary and nomadic lifestyles in which few individuals or groups are positioned at either diametric pole.

As with all forms of racialization, one outcome is that a homogenized group representation is produced for a heterogeneous set of people. Yet this always contains elements of continuity and change. Holloway (2003) for example, analyses print press representations of "gypsies" surrounding their participation in Appleby Fair (a major social event for Gypsy-Travellers in England) between the late Victorian and post-World War I eras. By the 1920s, she argues, the rural, authentic and horse-focused gypsies of the past had been replaced by "inauthentic" rural equivalents of the urban underclass. This comes quite close to the discourse of disgust and displacement surrounding the Tony Martin case (Vanderbeck 2003) in the 1990s, where a man shot dead a young Traveller burgling his home. I suggest that it neatly delineates the passage towards the newest incarnation of the twenty-first century: the cheating, freeloading green belt space invader.

\section{Reflexive racialization}

We noted above that racialization is a two-way street in that groups use it as means to produce and maintain collective identity. This is all the more glaring in the case of the distinctions maintained between Gypsy-Travellers and gaujo society. Gypsy-Travellers have a distrust of sedentary society's institutions, and there is a historical tension between the two ways of life (Okely 1983), particularly over the centrality of mobility, attitudes towards self-employment, the distinctions between workplace and home, for example.

So representations are imposed and Gypsy-Travellers resist assimilation that would ensue either through inter-marriage, or dilution of cultural practices. Boundaries get maintained and culture is transmitted. Racialization passes in both directions via cultural practices.

However, these observations do not enable us to understand what is new in the twenty-first century versions of the racialization of Gypsy-Travellers. For that we need to examine the historical conjuncture and trace the consequences of legislation. What might change look like; how does it happen, and what is the institutional mechanism? 


\section{Twenty-first century context for the racialization of Gypsy- Travellers}

\section{What is planning and what is the green belt?}

In order to develop an argument that planning regulations are a major (but not the exclusive) site for the racialization of Gypsy-Travellers, we need to understand both what the planning system is, and the space occupied in it by the "green belt".

The planning system (DCLG 2015) enables the government, acting through local authorities to plan and control a range of developments within their jurisdictions. ${ }^{4}$ People or organizations can develop property/land, or change the use to which property /land is put. Those living within a one-mile radius of a proposed development are consulted via the local authority's planning committee. There are differential rates of success for planning applications by Gypsy-Travellers and sedentary people (Nadeem 2012; Traveller Movement 2015). The pattern of inequitable planning permission identified in the ODPM (2004) report has not been neutralized since then. By 2015, there was still a noticeable discrepancy between the success rates of Travellers' and sedentary people's applications. Using figures from the official Planning Statistics Data (2010-15), the Traveller Movement (2015) argues that:

\footnotetext{
Between 2010 and 2015, major Traveller site applications were on average 11.6\% less likely to be granted when compared to applications for major Dwellings. For the same period minor Traveller site applications were on average $17.8 \%$ less likely to be granted permission when compared with applications for minor Dwellings. $^{5}$
}

Why is the success rate of planning applications from Gypsy-Travellers lower than that of sedentary people? Although local authorities are required - by both the 2012 National Planning Policy Framework, and the 2004 Housing Act - to meet the accommodation needs of the whole population within their area, this gap reflects local authorities' unwillingness to either build new sites or allow permission for Travellers to develop sites. Such camps, it is argued, will lower property prices and generate clean-up costs for the local authority (i.e. the local taxpayer). Costs figure centrally in discourse on Gypsy-Travellers (Richardson 2015). However, costs in the tens of millions of pounds associated with eviction (Greenfields and Smith 2010) are already borne across local authorities and central government. Indeed, Gypsy-Travellers have used the courts, through appeals over planning regulations: in regards to the Dale Farm evictions (2001-11), court bills and associated costs fall, depending on the source (and what is included) from $£ 2$ million to $£ 22$ million (Mirror 2012; Sawer and Ljunggren 2011).

Moreover, even central government initiatives aimed at unblocking the site development paralysis are not properly taken advantage of. The Guardian 
(Nadeem 2012) reported in 2012 that only $£ 46 \mathrm{~m}$ of the $£ 60 \mathrm{~m}$ in Homes and Communities Agency funding up for grabs until 2015, specifically for use in creating halting sites, had been bid for. Moreover, the five counties with the most Travellers and 25 per cent of the caravans (Essex, Kent, Cambridgeshire, Hertfordshire and Surrey) only got 4 per cent of the money. All these counties are under Conservative Party control.

\section{The "green belt", land and prices}

The green belt is a zone surrounding urban areas that is to be retained as natural undeveloped space. It grew out of discourse in Britain from the end of the nineteenth century (Kabachnik 2010). A policy aimed at preserving the green belt became a reality in the post-war period. This policy performs the role of protecting rural space by preventing uncontrolled building. As of 2016, the green belt accounted for approximately 13 per cent of land in the UK (DCLG 2016). In the debates over Traveller sites, their location in the green belt is often cited as a reason for their illegality, and moreover, as it is understood as unspoilt land, it can be "spoilt", or "sullied" in the national imagination, by "dirty" people who do not belong there (Sibley 1981).

Against a backdrop of rising housing prices, the South-East of England has witnessed a significant rise in prices since the 1980s (Forrest and Murie 2014). As housing and land for building have become increasing valuable, two things have happened. First, a dramatic rise in the price of land and property that means that for a substantial group of people, their home is now their principal asset (Dorling 2014). The stakes of planning are thus heightened, as development has an impact on house prices (or such is the firmly-held perception) (Garner 2013; Nowell 2015; Powell 2013).

Second, the marginal and "residual" peri-urban spaces traditionally occupied by Gypsy-Travellers until the end of the twentieth century (Sibley 1981) became correspondingly more valuable as they allowed construction of potentially lucrative residential or business properties and estates. So instead of moving uncontested in and out of those spaces, Gypsy-Travellers now faced competition for their use, impacting on their mobility and pushing them towards the even more contentious green belt locations. It is not coincidental that the 1994 Criminal Justice and Public Order Act was passed in this period.

\section{The 1994 criminal justice and public order act (CJPOA)}

Under the 1968 Caravan Sites Act, local authorities had been obliged to provide halting sites. Section 80 of the 1994 CJPOA repealed the 1968 Act, making the local authority duty optional rather than mandatory; and conferring powers on the police to move illegally settled people, and to control 
movement if public order were deemed at stake. Even the mandatory regime had not produced enough halting sites. Indeed, The Office of the Deputy Prime Minister's report (ODPM 2004) found that 90 per cent of halting sites had been closed in the decade preceding the inquiry (1994-2003), while both the Equalities and Human Rights Commission (2009) and Irish Traveller Movement (Hargreaves and Brindley 2011) reports on the UK stated that reaching the target number of halting sites at local government level was decades behind schedule. Moreover, Gypsy-Travellers often encountered violence from vigilante groups and/or the police force prior before and after the CJPOA. Indeed, experiencing vocally expressed anti-Traveller attitudes, and the experience of being moved on seem constitutive of Gypsy-Travellers identities (Powell 2013).

\section{The racialization of Gypsy-Travellers in the planning process}

So by the first decade of the twenty-first century, Gypsy-Travellers were subject to a discursive regime that identified them as unproductive undesirables; a legislative regime that criminalized their core cultural component (mobility); and an institution governing space (the planning regulations) which although neutrally framed, has in practice worked inequitably.

My argument over the centrality of planning in contemporary racialization of Gypsy-Travellers rests on the observation that non-Travellers' principal contact with Gypsy-Travellers is either directly or indirectly (through media reports) to do with planning process and its constituent elements: applications for permission; opposition to applications; illegal and or dirty occupation of land; appeals and the lengthy waiting between the various parts of the process. This is true of both local and national press. The headline, "Concerned residents face anxious wait over long running traveller camp dispute" (Robinson 2015) in a local newspaper report neatly summarizes the typical framing. In it, Gypsy-Travellers are usually positioned as the unreasonable party, unfairly enabled by local authorities and or central government to take advantage of the planning laws to the detriment of beleaguered locals and especially on the green belt (see Express and Star 2016; Hambridge 2016), whose status plays a significant role in the rationale for refusing planning permission. A series of amended multiple applications over a sustained period (Bury Free Press 2008) often forms the spine of this story, as Gypsy-Travellers combine retrospective applications with revised ones incorporating feedback from rejected versions.

However, the relatively neutral language and framings of the local press referred to in the previous paragraph stand in stark contrast to those of the major national daily newspapers. The Sun's famous "Stamp on the Camps" campaign in 2005 (Richardson and O'Neill 2013) is better known than the Daily Express's 2010 series of articles leading up to and just after the 
General Elections, framing the situation as a "scandal" (Henderson 2010a), a "war" (Lee 2010), Gypsy-Travellers as "invaders" (Pickard 2010), and the incoming government as proposing a welcome crackdown on "troublemaking travellers and gypsies" (Henderson 2010b), who camp illegally and take advantage of loopholes in planning law.

In terms of density and content of coverage, a brief comparison of the Daily Mail and the Daily Mirror gives an indicative picture (see Table 1). The Daily Mail's coverage in the twelve months to June 2017 features sixty-seven stories for example, twenty-nine of which centre on the illegal occupation of land and twelve on violence perpetrated by Gypsy-Travellers and seven on dirt and dumping. Only a handful of the others were neutral (on horse fairs). The Mirror featured sixty-four stories in the two-year period to June 2017; seventeen of which centre on the illegal occupation of land; fourteen on violence; and three on dirt and dumping. Four are positive: two each on a young woman who is first in her family to get a university place, and the winner of a reality television show called Big Brother.

This categorization is a merely a sketch requiring much more detailed follow-up work to develop nuance. However, I suggest that coverage of Gypsy-Travellers in tabloid media frames them as a source of anxiety and public expenditure, virtually never as normal citizens, and seldom with anything positive to contribute. Their interface with the settled population is largely mediated through planning regulations and the consequent (expensive) conflicts arising. Non-conflictual relationships between Gypsy-Travellers and settled populations (or within Gypsy-Traveller communities) exist (Richardson and Codona 2016) but are not newsworthy. These representations are thus also shaped by what dimensions of such relationships are absent from the coverage.

The outcome of the series of sporadic conflicts between Gypsy-Travellers, locals and local authorities over access to land since the beginning of the twenty-first century (with small local sites at one end of the spectrum and Dale Farm, Essex, at the other), has had the effect of transforming Gypsy-

Table 1. Thematic analysis of newspaper coverage of Gypsy-Travellers.

\begin{tabular}{lcc}
\hline Topic & $\begin{array}{c}\text { Mirror } \\
\text { (June 2015-June 2017) }\end{array}$ & $\begin{array}{c}\text { Mail } \\
\text { (June 2016-June 2017): }\end{array}$ \\
\hline Illegal occupation/eviction & 17 & 29 \\
Dirt left/dumping & 3 & 7 \\
Violence, threats & 14 & 12 \\
Other illegal activities & 5 & 3 \\
Horse fairs & 4 & 6 \\
Wealth & 6 & 0 \\
Funeral & 4 & 4 \\
GT as victims & 4 & 2 \\
Positive & 4 & 0 \\
Other & 6 & 4 \\
Total & 64 & 67 \\
\hline
\end{tabular}


Travellers into the embodiment of non-contributing, resource-cheating Others obtaining a valuable resource: land, by flouting rules that the deserving do not get. In the context of the mainstream framing, through which minorities are advantaged vis-à-vis white UK people (Garner 2015), this situation is translated into another example of political correctness, as Telegraph journalist Philip Johnston's respondent demonstrates: "It seems that if you are a member of an ethnic minority you have rights and if you are not you don't."

This script provides sedentary people with a tool for understanding GypsyTravellers as inherently deceitful and manipulative. Like all "power-evasive" discourses (Frankenberg 1994), it deflects attention both from the structural parameters framing the planning regulations and the historical context explaining how we arrived at this particular set of conflicts in this particular way.

\section{The conservative government's traveller planning policy}

In January 2016, the Conservative government produced new planning regulations explicitly addressing Gypsy-Travellers (Smith 2016). They include an explicit redefinition of membership of the Travelling community (that had been enshrined in the 2011 Census), and, contra the provisions of the 2004 Housing Act, removing settled Travellers from the Traveller population. The new definition proposed reads:

Persons of nomadic habit of life whatever their race or origin, including such persons who on grounds only of their own or their family's or dependants' educational or health needs or old age have ceased to travel temporarily, but excluding members of an organised group of travelling showpeople or circus people travelling together as such.

2. In determining whether persons are "gypsies and travellers" for the purposes of this planning policy, consideration should be given to the following issues amongst other relevant matters:

a) whether they previously led a nomadic habit of life

b) the reasons for ceasing their nomadic habit of life

c) whether there is an intention of living a nomadic habit of life in the future, and if so, how soon and in what circumstances' (Smith 2016, 13)

This definition also parallels a common sense understanding of Gypsy-Traveller culture voiced concisely by Johnston (2010) in his critique of social relations between settled and travelling communities:

Travellers are treated as a separate ethnic minority deserving of certain rights and respect for their culture. But if they are not travellers at all, in the sense 
that they intend to stay put like the rest of us, then surely they should be subject to precisely the same rules that apply to everyone else.

Myers' (2015) argument that the sedentary-non-sedentary binary in relation to Gypsy-Travellers is a contrived frame is borne out. The state's assertion of control makes it increasingly difficult to lead a mobile lifestyle, thus decreasing the group's capacity for enacting a core cultural practice. Moreover, Smith and Greenfields (2015) assert that Gypsy-Travellers who move into houses, and especially those housed by local authorities are "de-ethnicized" in official terms, disappearing from official statistics as a result: they are effectively removed from the Gypsy-Traveller population.

Moreover, the phrase "whatever their race or origin" suggests that the definition of group membership is only cultural, an assertion refuted by GypsyTravellers. Indeed, the response from the Traveller Movement to the entire package of changes referred to in the January 2016 Government Briefing paper on planning proposals (Smith 2016) demonstrates first, a disconnect between State and Gypsy-Traveller constructions of group membership, and second, what is important in determining planning outcomes. These latter include; replacing guidelines on carrying out needs analyses for Gypsy-Travellers alongside the elimination of a centrally imposed duty to include Gypsy-Travellers in planning at all; and a focus on making retrospective planning permission more difficult to obtain after "intentional unauthorised occupation of sites" (Smith 2016, 14).

"At the heart of these changes" comments the Traveller Movement (2015), "lies a deep misunderstanding of the culture and lives of England's Gypsies and Travellers and a failure by Government to meaningfully recognize their ethnic minority status in the planning system".

It should also be noted that the planning policy proposals also do two other important things. First, they explicitly prohibit Gypsy-Traveller settlement on green belt sites, while establishing a planned home-building programme for the green belt. Second, they focus on occupation of sites without recognizing the context in which illegal occupation becomes an enticing option. Moreover, the proposals make "intentional illegal settlement" of a site a punitive "significant material consideration" in retrospective planning applications, while a local authority's failure "to demonstrate an up-to-date five year supply of deliverable sites will no longer be a significant material consideration in planning decisions" (Traveller Movement 2015, 1).

The 2014-16 planning proposals thus constitute a major clampdown on Travellers, identifying them for differential treatment vis-à-vis the settled population, and attempting to reduce their numbers through a redefinition of group membership that runs against the group's own interpretation.

So a confluence of factors has produced the new configuration of frames and ideas. Neither the rise in the price of land and property nor the social 
construction and legal protection of the "green belt" in the UK are new phenomena, but without them, the impacts of the CJPOA (police powers to move people on and criminalize their use of un-authorized sites), coupled with the use of the planning process by Gypsy-Travellers would not have brought about a new normal: in which Gypsy-Travellers are associated with illegally occupying green belt and other space; cheating planning regulations applicable to everyone else; and most importantly, getting away with it. These processes have had two major outcomes for Gypsy-Travellers: a more sedentary lifestyle for some, and/or settlement on sites where retrospective planning permission has been applied for.

\section{Accommodation crises: impacts of legislative change on the incorporation of Gypsy-Travellers into English space}

I have argued throughout that a very long-term racialization process has become institutionalized differently in the English planning system over the last twenty years.

The role of the State includes shaping and passing legislation restricting mobility, and regulations surrounding planning, enforcing these laws and regulations differentially for Gypsy-Travellers. The structural forces determining the terrain within which Gypsy-Travellers act are clearly not amenable to them using the planning regulations and expecting the same results as the sedentary population. Indeed a "logic of genocide" (McVeigh 2008) is specifically envisioned in the English version, which seeks to assimilate Gypsy-Travellers into the settled population and then redefine group membership so that they disappear into the sedentary population (Smith and Greenfields 2015). This powerful tool consisting of having the ultimate say on who belongs to which group, is available only to the state. One of Cheryl Harris' case studies in her analysis of "whiteness as property" in the USA, is of the Native American Mashpee nation (1993, 1764-1766). The Mashpee's claims on expensive land get nullified in court because the state's definition of who a Mashpee can be ultimately excludes most of those that the Mashpee themselves think are Mashpee.

The combined effects of: the implementation of the CJPOA (criminalizing Gypsy-Travellers' mobility; and the backpedalling of local authorities on their now optional responsibility to provide halting sites); and the latest round of amendments to planning rules (including revising the definition of Gypsy-Traveller), have produced a new context for the racialization of Gypsy-Travellers in England in the first part of the twenty-first century.

In 2009, it was estimated by the Equality and Human Rights Commission (Brown and Niner 2009) halting site provision was at least 5,700 short (including around 1,000 "transit" sites).The number of Travellers living in illegal sites in Britain is now estimated at between 20,000 and 25,000 (Eccleston 2016). 
Gypsy-Travellers have begun to seek other solutions, i.e. "cultural adaptation", which include using the existing planning system, and/or moving into settled accommodation (around 200,000 of the 300,000 Gypsy-Travellers living in the UK). Given the reduced statistical likelihood of obtaining planning permission for sites, the principal tactic of resistance has consisted of individuals buying land then using it as a more permanent communal halting site, effectively sub-dividing the land, then applying for retrospective permission, as was the case at Dale Farm, in South-East England. ${ }^{6}$

So what impacts have planning regulations in the context of changes to the law had on Gypsy-Travellers? Smith and Greenfields $(2015,16)$ conclude that:

... the relationship of Gypsies and Travellers to the state is characterised by a cyclical relationship of domination, resistance and resilience,

and use Acton's (1974) four-part model of Traveller response to analyse this cycle. Its elements are: the "conservative approach" (minimize contact/withdraw in); "cultural disintegration" (a breakdown of traditional culture and values); "passing" (competing on equal terms in mainstream society and disguising ethnicity); and "cultural adaptation". I argue that it is the last of these that seems the most characteristic of twenty-first century Traveller responses.

The success of the state's assimilation policy and its current construction of obstacles placed in front of Gypsy-Travellers' access to space and the implementation of their culture, functions by convincing all the actors that Gypsy-Travellers are different from sedentary people primarily in terms of mobility. This binary is part of the racialization process: if the binary were replaced by a nuanced spectrum, Gypsy-Travellers and "sedentary" people would not be distributed distinctly from one another, and part of the basis for racialization crumbles. However, the tactic of resisting through bending planning regulations consequently brings Gypsy-Travellers into conflict with local residents and local authorities. Media report this as Gypsy-Travellers breaking rules and generating costs (legal fees, eviction and clean-up), discursively producing them as tax and planning cheats costing the ordinary taxpayer. Sedentary taxpayers thus simultaneously produce Gypsy-Travellers as sponging, advantage-taking and threatening Others, and themselves as hardworking and ethical victims of the politically correct state.

The key point is that in terms of racialization, the outcome, which is GypsyTravellers living on illegal sites (be they on the roadside or on land whose planning permission was granted for a different usage) has been arrived at through complex processes of engagement with the mechanism of planning regulations, within the institution of the English planning system. Yet in the discourse framed in the media and politics (agents) it is presented simply as a choice made by Gypsy-Travellers (objects of discourse) to circumvent 
the law: the implication being that cheating is a cultural norm. So "cultural adaptation" ends up fuelling racialization.

There are of course significant cultural distinctions between Gypsy-Travellers and those shorthanded as "sedentary" populations, which should not be disregarded. Indeed reflexive racialization is all about maintaining them. Yet the racialization of Gypsy-Travellers described above also acts as an effective brake on the development of some political alliances. The racial/ethnic frame now used to claim human rights necessarily leads to an over-emphasis on difference and an underplaying of commonalities. This is not an "either/or" argument, but a "both/and" one. Using the "ethnic minority" frame, alliances can be sought with other groups deploying the same frame, as in the case of contemporary Traveller social movements such as the Traveller Movement, and Friends, Families and Travellers. However, the issue-based aspects of struggle are often subsumed into the identitybased ones. Gypsy-Travellers are facing the full force of an accommodation crisis, but so are many "sedentary" people locked into homelessness, privatesector renting, overcrowding, and couch surfing because they cannot afford to purchase homes (MacKie and Thomas 2014). Discourse on this crisis is dominated by government, housebuilders and landlords (Dorling 2014). A space for alliance between Gypsy-Travellers and sedentary groups over principles governing resource allocation for accommodation exists. Yet it is one of the resounding successes of the racialization of Gypsy-Travellers in England that this field is relentlessly cast as a competition between Gypsy-Travellers and others, when it might be more accurate to depict this as one aspect of a much broader historic struggle between the landless and the land-owning.

\section{Notes}

1. "Ethnicity" is constructed as primarily a neutral, descriptive term indicating cultural distinctions, and thus useful for governance, whereas "race" is immediately more conflictual. However, ethnicity is quite often used as a synonym for "race" in British discourse. It can also be politically mobilised by Gypsy-Travellers (McGarry 2014).

2. I have left "perceived" here because I want my definition to speculatively cover mobilizations, or "racial projects" involving white people who identify themselves as racially de-prioritised (rather than by class) vis-à-vis ethnic minority groups. The trick would be to distinguish the white supremacy projects from the others. This is not the place to make that case, but it requires increasing attention in the Brexit/Trump era.

3. For those interested in the details, there is much in the cultural distinctions examined by Okely (1983) as a starting point, and Okely (2014) for an update. At the 2011 Census, the first time when Gypsy-Travellers could identify themselves specifically, 58,000 people in England and Wales ticked this box $(0.1$ per cent of the resident population). Gypsy-Traveller organizations on the 
other hand estimate the population as closer to 300,000.Longstanding suspicion of sedentary society institutions could well explain under-reporting.

4. Alternatively, see Royal Town Planning Institute: http://www.rtpi.org.uk/ planning-aid/planning-explained/ or House of Commons (2016) for a comparison of the planning systems in the four UK countries.

5. "Minor dwellings" is defined as fewer than 9 buildings on an area of 0.5 hectares or below.

6. Dale Farm, near Basildon, England, ended up as the largest Gypsy-Traveller camp in Europe, with an estimated 1,000 people living there before the illegal half was shut down and evictions finished in October 2011.

\section{Disclosure statement}

No potential conflict of interest was reported by the author.

\section{References}

Acton, Thomas. 1974. Gypsy Politics and Social Change. London: Routledge and Kegan Paul. Bancroft, Angus. 2001. "Closed Spaces, Restricted Places: Marginalisation of Roma in Europe." Space and Polity 5 (2): 145-157.

Bhopal, Kalwant. 2011. "What About Us?' Gypsies, Travellers and 'White Racism' in Secondary Schools in England." International Studies in Sociology of Education 21 (4): 315-329.

Brewer, Rose, and Nancy Heitzeg. 2008. "The Racialization of Crime and Punishment." American Behavioral Scientist 51 (5): 625-644.

Brown, Philip, and Pat Niner. 2009. "Assessing Local Housing Authorities' Progress in Meeting the Accommodation Needs of Gypsy and Traveller Communities in England." Research Report: 13. London: Equalities and Human Rights Commission.

Bury Free Press. 2008. "Beck Row: New Bid for Travellers' Site." 7 May. http://www. buryfreepress.co.uk/news/beck-row-new-bid-for-travellers-site-1-410603.

Carter, Bob, Clive Harris, and Shirley Joshi. 1987. "The 1951-55 Conservative Government and the Racialization of Black Immigration." Immigrants \& Minorities 6 (3): 335-347.

Casey, Rionach. 2014. "Caravan Wives' and 'Decent Girls': Gypsy-Traveller Women's Perceptions of Gender, Culture and Morality in the North of England." Culture, Health \& Sexuality 16 (7): 806-819.

Cemlyn, Sarah, Margaret Greenfields, Sally Burnett, Zoe Matthews, and Chris Whitwell. 2009. Inequalities Experienced by Gypsy and Traveller Communities: A Review. Equality and Human Rights Commission, Report 12. https://www.equalityhumanrights.com/ sites/default/files/research_report_12inequalities_experienced_by_gypsy_and_ traveller_communities_a_review.pdf.

Clark, Colin. 2006. "Defining Ethnicity in a Cultural and Socio-Legal Context: The Case of Scottish Gypsy/Travellers." Scottish Affairs 54: 39-67.

Clough Marinaro, Isabella, and Nando Sigona. 2011. "Introduction Anti-Gypsyism and the Politics of Exclusion: Roma and Sinti in Contemporary Italy." Journal of Modern Italian Studies 16 (5): 583-589.

DCLG. 2015. Plain English Guide to the Planning System. https://www.gov.uk/ government/uploads/system/uploads/attachment_data/file/391694/Plain_English_ guide_to_the_planning_system.pdf. 
DCLG. 2016. Local Planning Authority Green Belt: England 2015/16. Planning: Statistical Release, September 8.

Dorling, Danny. 2014. All That Is Solid: How the Great Housing Disaster Defines Our Times, and What We Can Do About It. London: Penguin.

Durrheim, Kevin, and John Dixon. 2001. "The Role of Place and Metaphor in Racial Exclusion: South Africa's Beaches as Sites of Shifting Racialization." Ethnic and Racial Studies 24 (3): 433-450.

Eccleston, Ben. 2016. "Travellers Group Says Councils Should Provide Permanent Sites Rather than Spend £20m a Year on Evictions." Coventry Evening Telegraph, 8 January. http://www.coventrytelegraph.net/news/coventry-news/travellers-group-sayscouncils-should-10704031.

Eng, David. 2010. The Feeling of Kinship: Queer Liberalism and the Racialization of Intimacy. Durham, NC: Duke University Press.

Equalities and Human Rights Commission. 2009. Gypsies and Travellers: Simple Solutions for Living Together. London: EHRC.

Express and Star. 2016. "Traveller Site Saga to be Settled at Inquiry." 3 February. http:// tinyurl.com/ybvggqqy.

Forrest, Ray, and Alan Murie. 2014. Selling the Welfare State: The Privatisation of Public Housing. London: Routledge.

Foucault, Michel. 2003. Society Must Be Defended: Lectures at the Collège de France, 197576. London: Allen Lane.

Fox, John, Laura Moroşanu, and Eszter Szilassy. 2015. "Denying Discrimination: Status, 'Race', and the Whitening of Britain's New Europeans." Journal of Ethnic and Migration Studies 41 (5): 729-748.

Frankenberg, Ruth. 1994. White Women, Race Matters. Madison: University of Wisconsin Press.

Garner, Steve. 2007. Whiteness: An Introduction. London: Routledge.

Garner, Steve. 2013. "The Racialisation of Asylum in Provincial England: Class, Place and Whiteness." Identities 20 (5): 503-521.

Garner, Steve. 2015. A Moral Economy of Whiteness. London: Routledge.

Gentleman, Amelia. 2017. "Fighting Gypsy Discrimination: 'What People Ask Me Is Insulting'." Guardian, 17 May. https://www.theguardian.com/world/2017/may/16/ gypsy-travellers-discrimination-stigma-poster-campaign?CMP=share_btn_tw.

Goldberg, David. 2000. The Racial State. Boston: Blackwell.

Goodman, Simon, and Lottie Rowe. 2014. "'Maybe It Is Prejudice... But It Is NOT Racism': Negotiating Racism in Discussion Forums About Gypsies." Discourse \& Society 25 (1): 32-46.

Greenfields, Margaret, and David Smith. 2010. "Housed Gypsy Travellers, Social Segregation and the Reconstruction of Communities." Housing Studies 25 (3): 397-412.

Hambridge, Karen. 2016. "Five-Year Fight for Hinckley Traveller Site Rumbles On." Hinckley Times, 22 November. http://www.hinckleytimes.net/news/local-news/fiveyear-fight-hinckley-traveller-12189001.

Harell, Allison, Stuart Soroka, and Kiara Ladner. 2014. "Public Opinion, Prejudice and the Racialization of Welfare in Canada." Ethnic and Racial Studies 37 (14): 2580-2597.

Hargreaves, Michael, and Matthew Brindley. 2011. Planning for Gypsies and Travellers: The Impact of Localism. London: Irish Traveller Movement in Britain.

Harris, Cheryl. 1993. "Whiteness as Property." Harvard Law Review 106: 1707-1791.

Henderson, Eugene. 2010a. "Scandal of Unwanted Gypsy Sites." Daily Express, 7 February. http://www.express.co.uk/news/uk/156691/Scandal-of-unwanted-gypsysites. 
Henderson, Eugene. 2010b. "Gypsy Camp Crackdown." Daily Express, 23 May. http:// www.express.co.uk/posts/view/176672/Gypsy-camp-crackdownGypsy-campcrackdownGypsy-camp-crackdown.

Holloway, Sarah. 2003. "Outsiders in Rural Society? Constructions of Rurality and Nature - Society Relations in the Racialisation of English Gypsy-Travellers, 1869-1934." Environment and Planning D: Society and Space 21: 695-715.

Holloway, Sarah. 2005. "Articulating Otherness? White Rural Residents Talk About Gypsy-Travellers." Transactions 30: 351-367.

House of Commons. 2016. Comparison of the Planning Systems in the Four UK Countries. Commons Library Briefing Paper 07459. http://researchbriefings.files.parliament.uk/ documents/CBP-7459/CBP-7459.pdf.

Johnston, Philip. 2010. "Settled Travellers Should Live by Our Rules." Daily Telegraph, 31 August. http://www.telegraph.co.uk/comment/columnists/philipjohnston/7972484/ Settled-travellers-should-live-by-our-rules.html.

Kabachnik, Peter. 2010. "Place Invaders: Constructing the Nomadic Threat in England." Geographical Review 100 (1): 90-108.

Kenrick, Donald, and Grattan Puxon. 1972. The Destiny of Europe's Gypsies. Brighton: Sussex University Press.

Lee, Adrian. 2010. "Our Gypsy War." Daily Express, May 8. http://www.express.co.uk/ expressyourself/173920/Our-gypsy-war.

Lipsitz, George. 2007. "The Racialization of Space and the Spatialization of Race: Theorizing the Hidden Architecture of Landscape." Landscape Journal 26 (1): 10-23.

MacKie, Peter, and lan Thomas. 2014. Nations Apart? Experiences of Single Homelessness Across Great Britain. London: Crisis.

Maldonado, Maria. 2009. "It Is Their Nature to Do Menial Labour': The Racialization of 'Latino/a Workers' by Agricultural Employers." Ethnic and Racial Studies 32 (6): 1017-1036.

Mayall, David. 2004. Gypsy Identities 1500-2000: From Egipcyans and Moon-men to the Ethnic Romany. London: Routledge.

McGarry, Aidan. 2014. "Roma as a Political Identity: Exploring Representations of Roma in Europe." Ethnicities 14 (6): 756-774.

McVeigh, Robbie. 2008. "The 'Final Solution': Reformism, Ethnicity Denial and the Politics of Anti-Travellerism in Ireland." Social Policy and Society 70 (1): 91-102.

Mirror. 2012. "Dale Farm Travellers' Site Evictions Cost Nearly £2.4m." 23 January. http:// www.mirror.co.uk/news/uk-news/dale-farm-travellers-site-evictions-188697.

Morris, Rachel. 2000. "Gypsies, Travellers and the Media: Press Regulation and Racism in the UK." Tolleys Communications Law 5 (6): 213-219.

Murji, Karim, and John Solomos, eds. 2005. Racialization: Studies in Theory and Practice. Oxford: Oxford University Press.

Myers, Martin. 2015. "Traveller Planning Policy Continues to Marginalise Gypsy Families." LSE Blogs, 5 November. http://blogs.Ise.ac.uk/politicsandpolicy/50898-2/.

Nadeem, Beena. 2012. "Political Suicide: Housing Gypsy and Traveller Communities." Guardian, 16 July. https://www.theguardian.com/housing-network/2012/jul/16/ local-politics-housing-gypsies-and-travellers.

Nicolae, Valeriu, and Hannah Slavik. 2003. "Being a 'Gypsy': The Worst Social Stigma in Romania." European Roma Rights Centre, 13 May. http://www.errc.org/article/beinga-gypsy-the-worst-social-stigma-in-romania/1385.

Nowell, Andrew. 2015. "Fury at Home Sale 'Blighted' by Traveller Neighbours." Wigan Today, 30 March. http://www.wigantoday.net/news/fury-at-home-sale-blighted-bytraveller-neighbours-1-7183765. 
Office of the Deputy Prime Minister. 2004. Gypsy and Traveller Sites', Vol. 1: Thirteenth Report of Session 2003-04. London: HMSO.

Okely, Judith. 1983. The Traveller-Gypsies. Cambridge: Cambridge University Press.

Okely, Judith. 2014. "Recycled (mis)Representations: Gypsies, Travellers or Roma Treated as Objects, Rarely Subjects." People, Place and Policy Online 8 (1): 65-85.

Parker, David, and Miri Song. 2006. "New Ethnicities Online: Reflexive Racialisation and the Internet." The Sociological Review 54 (3): 575-594.

Parry, Glenys, Patrice Van Cleemput, Jean Peters, Stephen Walters, Kate Thomas, and Cindy Cooper. 2007. "Health Status of Gypsies and Travellers in England." Journal of Epidemiology and Community Health 61 (3): 198-204.

Pickard, Michael. 2010. "Villagers Raise $£ 225 k$ to Buy Off Gypsy Invaders." Daily Express, 17 May. http://www.express.co.uk/news/uk/175533/Villagers-raise-225k-to-buy-offgypsy-invaders.

Powell, Ryan. 2013. "Loïc Wacquant's 'Ghetto' and Ethnic Minority Segregation in the UK: The Neglected Case of Gypsy-Travellers." International Journal of Urban and Regional Research 37 (1): 115-134.

Quinn, David. 1966. The Elizabethans and the Irish. Ithaca: Cornell University Press.

Richardson, Joanna. 2015. The Gypsy Debate: Can Discourse Control? Exeter: Imprint Academic.

Richardson, Joanna, and Janie Codona. 2016. Managing and Delivering Gypsy and Traveller Sites: Negotiating Conflict. Coventry: Chartered Institute of Housing on behalf of JRF and De Montfort University. http://www.cih.org/resources/PDF/Policy \%20free\%20download\%20pdfs/GypsyTravellerSitesDec16.pdf.

Richardson, Joanna, and Richard O'Neill. 2013. "'Stamp on the Camps': The Social Construction of Gypsies and Travellers in Media and Political Debate." In Gypsies and Travellers: Empowerment and Inclusion in British Society, edited by Joanna Richardson and Andrew Ryder, 169-186. Bristol: Policy Press.

Robinson, Jon. 2015. "Concerned Residents Face 'Anxious' Wait Over Long-Running Traveller Camp Dispute." Lancashire Telegraph, 19 September. http://www. lancashiretelegraph.co.uk/news/13770712.Concerned_residents_face anxious_wait_over_long_running_traveller_camp_dispute/.

Rowe, Lottie, and Simon Goodman. 2014. "'A Stinking Filthy Race of People Inbred with Criminality' A Discourse Analysis of Prejudicial Talk About Gypsies in Discussion Forums." Romani Studies 24 (1): 25-42.

Sawer, Patrick, and Hanna Ljunggren. 2011. "The $£ 22$ Million Cost of Evicting the Dale Farm Travellers." Daily Telegraph, 2 October. http://www.telegraph.co.uk/news/ uknews/law-and-order/8800962/The-22-million-cost-of-evicting-the-Dale-Farmtravellers.html.

Sibley, David. 1981. Outsiders in Urban Societies. Oxford: Blackwell.

Smith, Louise. 2016. Gypsies and Travellers: Planning Provisions. House of Commons Library Briefing Paper Number 07005, 4 January: www.researchbriefings.files. parliament.uk/documents/SN07005/SN07005.pdf.

Smith, David, and Margaret Greenfields. 2015. "Resisting Assimilation: Survival and Adaptation to 'Alien' Accommodation Forms. The Case of British Gypsies/Travellers in Housing." Today's Children Tomorrow's Parents: An Interdisciplinary Journal 40-41: 68-81.

Stewart, Michael. 2013. "Roma and Gypsy 'Ethnicity' as a Subject of Anthropological Inquiry." Annual Review of Anthropology 42: 415-432.

Taylor, Rebecca. 2008. A Minority and the State: Travellers in Britain in the 20th Century. Manchester: Manchester University Press. 
Traveller Movement. 2015. "Government Changes to Planning Policy for Traveller Sites." http://www.travellermovement.org.uk/wp-content/uploads/2015/09/NewGovernment-changes-to-Planning-Policy-for-Traveller-sites-September-20151.pdf.

Van Cleemput, Patrice. 2012. "Gypsy Traveller Health." In Gypsies and Travellers: Empowerment and Inclusion in British Society, edited by Joanna Richardson and Andrew Ryder, 43-60. Bristol: Policy Press.

Vanderbeck, Robert. 2003. "Youth, Racism, and Place in the Tony Martin Affair." Antipode 35 (2): 363-384.

Wolfe, Patrick. 2002. "Race and Racialisation: Some Thoughts." Postcolonial Studies 5 (1): 51-62. 